logos_i_ethos_2019_2_(50), s. 143-158

DOI: http://dx.doi.org/10.15633/lie.3482

Witold Nowak

https://orcid.org/0000-0002-3799-1851

Uniwersytet Rzeszowski

\title{
Rzecz jako fetysz. O moralności konsumpcji
}

\author{
„Rzecz jest rzeczą, \\ a nie opinią o tej rzeczy" - Birdman ${ }^{1}$
}

\section{Fetysze}

Wyraz „fetysz” pochodzi z języka portugalskiego (w którym feitico używane było już w XIV wieku), a upowszechnił się w wersji francuskiej (fetiche). Źródłosłów łaciński tych słów to facticius - sztuczny,

Witold Nowak - dr hab., profesor Uniwersytetu Rzeszowskiego, kierownik Zakładu Kulturoznawstwa, zajmuje się filozofią kultury, filozofią historii i antropologią filozoficzną. Ostatnio wydał: Cnoty. Eseje z filozofii kultury (współredakcja, Rzeszów 2016) i Ciało, rzecz, pamięć. Rozprawy i eseje z filozofii kultury (współredakcja, Rzeszów 2017). stworzony. Portugalskie feitico odnoszono do artefaktów i oznaczało ono wtedy bądź to, że rzecz została wytworzona, bądź że została zaczarowana. Słowo to stosowane było ponadto w odniesieniu do amuletów i relikwii świętych ${ }^{2}$. Portugalscy żeglarze używali go wobec afrykańskich rzeźbionych figurek, które uczestniczyły w obrzędach magiczno-religijnych: figurki te były feiticos albo posiadały feitic ${ }^{3}$.

Powstające teorie fetyszyzmu wywodziły z kultu fetyszów (figurek kultowych) wszystkie religie (Charles de Brosses) bądź uznawały fetyszyzm

1 Zdanie-motto otwierające film Birdman (2014) w reżyserii A. G. Inárritu.

2 Por. J. Pysiak, Król i Korona Cierniowa. Kult relikwii we Francji Kapetyngów, Warszawa 2012.

3 Por. S. Sikora, Kilka uwag o fetyszu i fotografii, w: Rzeczy i ludzie. Humanistyka wobec materialności, red. J. Kowalewski, W. Piasek, M. Śliwa, Olsztyn 2008, s. 237-260. 
za stopień pierwszej fazy rozwoju ludzkiej inteligencji. Pojęcie fetyszyzmu było silnie obecne w ewolucjonistycznych teoriach kultury i religii, skupionych na wyróżnianiu faz rozwoju ludzkości (np. Edward Taylor, Friedrich Engels, John Lubbock) i związanych z nim deprecjonowaniu faz wcześniejszych jako prymitywnych. Fetyszyzm traktowany bywał $\mathrm{w}$ tych teoriach jako jedyna religia pierwotna wyznawana w społecznościach plemiennych. Dzięki nowszym badaniom etnologicznym ustalił się pogląd, że w fetyszyzmie rzeczy (amulety, talizmany) nie są czczone same w sobie, lecz ich kult obejmuje jedynie siłę wcielającą się w materialną postać. Cześć nie dotyczy zatem samej rzeczy, lecz sakralnej mocy, którą wprowadza się w rzecz, która wtedy staje się fetyszem; gdy moc odchodzi, przedmiot staje się bezużyteczny ${ }^{4}$.

Źródeł fetyszyzmu upatrywać można w spontanicznych reakcjach wyzwalanych myśleniem życzeniowym. „W toku dziejów przenoszono je na zoo- $i$ antropomorficzne idole, potem - $w$ miarę rozwoju myślenia abstrakcyjnego - na bardziej wysublimowane obiekty, duchy, demony i ostatecznie bóstwa"s. Za wywodzące się z fetyszyzmu uznawano współczesny kult maskotek, kult betyli, idoli, buddyjskich i chrześcijańskich relikwii, ikon, rzeźb czy Czarnego kamienia w Mekce.

Pojęcia fetysza (i fetyszyzacji) używa dziś wielu autorów, czyniąc to niekiedy zamiennie z takimi pojęciami, jak ikona czy przedmiot kultowy. Sporo tu niejasności, a także nadużywania i fetyszyzowania pojęć fetysza i fetyszyzmu. Remo Bodei, współczesny filozof włoski, pisze: „W określonych okolicznościach wyładowywanie energii libidinalnej na przedmiotach może przekształcić się w fetyszyzm. Za sprawą synekdochy (pars pro toto) jakaś część garderoby czy fotografia wypełnia się więc wszechobejmującym erotycznym znaczeniem, znaczeniową nadwyżką lub - w przypadku afrykańskich bożków, od których wzięło swą nazwę samo zjawisko fetyszyzmu - w ogóle treściami kulturowymi

4 Por. A. Szyjewski, Fetyszyzm, w: Religia. Encyklopedia PWN, red. T. Gadacz, B. Milerski, t. 4, Warszawa 2002, s. 23-24.

5 A. Szyjewski, Fetyszyzm, dz. cyt., s. 23. 
czy religijnymi” ${ }^{\circ}$. Człowiek „obsadza” energią libidinalną bardzo różne obiekty, które w ten sposób zyskują - nierzadko wielki - przyrost mocy. Stosunek „fetyszystów” do tak wzmocnionych znaczeniowo przedmiotów bywa nieczytelny i zadziwiający dla otoczenia.

\section{Odczarowanie?}

Jedna z najbardziej wpływowych teorii nowoczesności, teoria Maxa Webera, ujmuje nowoczesność jako proces narastającego odczarowywania świata ${ }^{7}$. Entzauberung dokonuje się pod przemożnym wpływem nauki pomnażanym przez sukcesy naukotechniki. Sprowadzają one świat do zestawu kwantyfikowalnych i dowolnie rozporządzalnych obiektów. Rzeczy zostają pozbawione immanentnego znaczenia, a cały świat staje się „światem bez kulis”. Taka perspektywa zmusza człowieka do samodzielnego poszukiwania sensu zdarzeń i sensu własnego życia. Charles Taylor mówi w tej sytuacji o potrzebie ponownego zaczarowania świata, potrzebie reakcji romantycznej. Ona to za pomocą subtelniejszego języka aniżeli dominujący język nauk naprowadzi nas na ukryte znaczenia rzeczy, które mogą rezonować w ludzkim wnętrzu, a nawet prowadzić do indywidualnych epifanii ${ }^{8}$. W tym kierunku podążały też $\mathrm{w}$ wieku XX liczne, nawiązujące do romantyzmu koncepcje wzmagania uwa$\mathrm{gi}^{9}$. Ich rdzeniem jest postulat uważnego patrzenia na świat, postulat widzenia rzeczy takimi, jakimi są, oraz pozwolenie rzeczom być.

$\mathrm{W}$ pogłębionych analizach wychodzi na jaw, że świat po oświeceniu nie jest bynajmniej światem odczarowanym. Pomimo panowania naukotechniki, która rozporządza rzeczywistością i traktuje naturalia jako

6 R. Bodei, O życiu rzeczy, przeł. A. Bielak, przekład przejrzeli i poprawili M. Salwa i K. Skórska, Łódź 2016, s. 44.

7 Zob. M. Weber, Racjonalność, władza, odczarowanie, wybór, wstęp, przekład M. Holona, Poznań 2004, s. 8n.

8 Zob. Ch. Taylor, Źródła podmiotowości. Narodziny tożsamości nowoczesnej, przeł. zespół, wstęp A. Bielik-Robson, oprac. nauk. T. Gadacz, Warszawa 2012, s. 837.

9 Por. Z. Król, Powrót do świata. Dzieje uwagi w filozofii i literaturze XX wieku, Warszawa 2013. W kinie podejście tego rodzaju spotykamy w filmach Jima Jarmuscha, zob. Paterson (2016). 
zasób i surowiec dla ludzkich przedsięwzięć (co tak dobitnie akcentował Martin Heidegger) przypisujemy rzeczom - niejako wbrew temu, w co wierzymy, że wiemy - ogromną liczbę znaczeń. Fenomen ten jest najbardziej zauważalny w przypadku fetyszyzmu towarowego zanalizowanego przez Karola Marksa w Kapitale ${ }^{10}$.

Dokonując krytyki fetyszyzmu towarowego, Marks posłużył się przykładem mebla, a dokładnie stołu. Oto stół przestaje być dla ludzi drewnem, kiedy nada mu się konkretną formę. Jednakże to właśnie forma, a nie włożony w wytwórstwo nakład ludzkiej pracy jest dla społeczeństwa wyznacznikiem wartości przedmiotu. Związek między wartością rzeczy-artefaktu a pracą jest daleki od jednoznaczności, zapośredniczony przez rozmaite sensy symboliczne.

Rzeczywistą wartość rzeczy-towaru określa u Marksa siła pracy, jaka doprowadziła do jego powstania. Natomiast cena dyktowana przez oferentów na rynku jest iluzją, produkt ją przesłania. Cena produktu nie odzwierciedla bynajmniej wartości pracy i maskuje społeczne relacje produkcji. Fetyszyzm towarowy polega na potraktowaniu towarów tak, jakby były osobami wyposażonymi w działanie. Tworzymy produkty, które natychmiast uzyskują własne życie, wymykając się naszej kontroli i formują nasze życie. Społeczeństwo, które fetyszyzuje towary, niszczy autentyczne relacje międzyludzkie.

Jako antidotum na powyższy patologiczny system Marks postulował powrót do wartości użytkowej rzeczy. Chciał na powrót organicznie powiązać produkcję z konsumpcją, pozbyć się przepełnionego iluzjami dystansu między nimi. Jego zdaniem bowiem fetyszyzowane towary naprawdę tyranizują relacje społeczne. Wizji tej zarzucano pewien romantyzm i podzielanie dominującej w XIX wieku apoteozy pracy, racjonalności i wartości użytkowej. Innymi słowy, Marks fetyszyzował wartość użytkową, pojmując ją jako w zupełności opartą na ludzkich potrzebach. Tim Dant w swej przenikliwej książce o kulturze materialnej ożywia klasyczne pytanie, czy istotnie nasze potrzeby wynikają

10 Zob. K. Marks, Kapitał, t. 1, ks. 1, Krytyka ekonomii politycznej, przeł. H. Lauer, Warszawa 1970, s. 140n. 
wprost $\mathrm{z}$ natury ${ }^{11}$. Nowsze refleksje nad konsumpcją, np. prace Jeana Baudrillarda $^{12}$, starają się raczej pokazać, że zarówno potrzeby ludzkie, jak i wartość użytkowa rzeczy same wynikają z procesów społecznego konstruowania rzeczywistości.

Zasady sprawiedliwości i uczciwości wymagają, aby człowiek płacący za określony towar otrzymywał to, co tradycyjnie nazywamy dobrą rzeczą: trwałą, względnie niezawodną, wytworzoną zgodnie z przemyślanym projektem estetycznym. Tak wykonana rzecz (zegarek, siekiera, rower, krzesło) służy człowiekowi w trakcie życia. We współczesnym systemie konsumpcji otrzymujemy jednak najczęściej towary świadomie postarzone przez producentów. Wokół tej kwestii trwa zmowa milczenia, a maskowaniu sytuacji służy wyrafinowana reklama. Wszystko to - praktyki produkcji, reklamy i sprzedaży - jest niezgodne z takimi cnotami, jak rzetelność, uczciwość, prawdomówność i sprawiedliwość. Klient, sprzedawca i producent wiedzą bowiem o dokonującym się oszustwie. Materiałowe i techniczne słabości rzeczy „rekompensuje się”, przydając rzeczom dodatkowe znaczenia, czyniąc z nich znaki i wiążąc z promowanymi stylami życia. Na tej drodze system towarów staje się skomplikowany aż do nieprzejrzystości ${ }^{13}$. Dlatego właśnie do współczesnego systemu produkcji można odnieść klasyczną definicję fetyszyzmu, zgodnie z którą to nie sam przedmiot posiada moc, lecz owa moc może mu być na jakiś czas udzielona, a następnie przeniesiona na inny przedmiot. Tę samą moc, którą uzyskują dzięki uporczywej reklamie sportowe buty Nike air max, można przenieść na akcesoria podróżne lub wyroby skórzanej galanterii.

11 Zob. T. Dant, Kultura materialna w rzeczywistości społecznej: wartości, działania, style życia, przeł. J. Barański, Kraków 2007, s. 46.

12 M. Schuster, Don DeLillo, Jean Baudrillard and the Consumer Conundrum, New York 2008, s. $37 \mathrm{n}$.

13 Por. R. Drozdowski, Obraza na obrazy. Strategie społecznego oporu wobec obrazów dominujących, Poznań 2006, s. 231-237. 


\section{Fetyszyzm i luksus}

Otaczanie czcią rzeczy, zwłaszcza przedmiotów bezpośredniego użytku, przypisywanie im bardzo wysokiej wartości jest sprzeczne z głównym nurtem filozofii Zachodu. W filozofii naszego kręgu kulturowego wolnemu człowiekowi przypisywano zawsze wartość wyższą aniżeli rzeczom. U starożytnych Rzymian jedynie niewolnicy traktowani byli jak rzeczy i narzędzia oraz zrównani z nimi pod względem wartości, np. Warron pod adresem niewolnika użył frazy „narzędzie mówiące” (instrumentum vocale). W średniowiecznej ontotelogii człowiek, homo, usytuowany był pośrodku hierarchii bytów (scala naturae), mając pod sobą - niższe pod względem stopnia doskonałości i wartości - zwierzęta, rośliny, minerały i rzeczy (res). Godność osoby przypisywano wyłącznie człowiekowi: persona to wręcz nomen dignitatis ${ }^{14}$. Łatwo oczywiście wskazać liczne praktyki będące wyjątkami od powyższych postaw (handel ludźmi, prostytucja, handel organami ludzkimi), jednak ludzie o rozwiniętym zmyśle moralnym traktowali je zawsze jako szkodliwe aberracje, a jeszcze inni skrywali pod płaszczem hipokryzji.

Jawny fetyszyzm, powtórzmy, pozostaje w sprzeczności z głównymi prądami filozofii Zachodu. W zgodzie z teorią pozostawało niegdyś praktyczne życie filozofów, którzy z reguły wiedli życie surowe pod względem materialnym, niekiedy wręcz ascetyczne ${ }^{15}$. Asceza (od gr. askein - ćwiczyć się) była niezbywalną częścią starożytnych koncepcji filozoficznego sposobu życia, który wymagał od adepta jedności theoria i praxis.

Życie społeczne biegło jednak własnymi torami. Od starożytności ludzkość kultywowała luksus. Peter McNeil i Giorgio Riello piszą: „Od czasów rzymskich ścisła definicja luksusu oparta była na semantycznym pokrewieństwie między słowem luxus (oznaczającym przepych,

14 Por. R. Spaemann, Osoby. O różnicy między czymś a kimś, Warszawa 2011, s. 4.

15 Por. D. W. Hamlyn, Being a Philosopher. The History of a Practice, London-New York 1994, passim. Warto w tym kontekście przywołać postać Ludwiga Wittgensteina, który zrzekł się ogromnego majątku na rzecz swoich sióstr, uznając, iż jest on szkodliwy dla prowadzenia życia filozoficznego. Ze stosunkowo luksusowego trybu życia słynął konserwatywny filozof polityki Allan Bloom. Por. S. Bellow, Suma po przemyśleniach, przeł. T. Bieroń, Poznań 1998, passim. 
pompatyczność, ale również zmysłowość) i jego derywatem luxuria (rozpusta, nieumiarkowanie i ekstrawagancja). Żadne z tych słów nie ma pozytywnej konotacji i z tego powodu uważano luksus za zjawisko problematyczne i negatywne pod wieloma względami”" ${ }^{16}$. Cyceron uważał, że z luksusu nieuchronnie wynika skąpstwo, inni Rzymianie widzieli jego następstwa w samolubstwie i podkopywaniu ducha obywatelskiego. Niebezpieczny był zwłaszcza, właściwy choćby Petroniuszowi, eruditio luxu, wymyślny zbytek.

Chrześcijańska moralność wieków średnich sugerowała - za Augustynem - że rzeczy materialnych należy używać stosownie do potrzeb człowieka (uti), lecz nie są one godne cieszenia się nimi, rozkoszowania $(\text { frui })^{17}$. W tym duchu John H. Newman mówił o podziwianiu tego, co doczesne przez odmowę. A jednak Jacques Le Goff sytuuje narodziny bliskich nam odmian luksusu już w XIII wieku, w czasie rozkwitu chrześcijaństwa. Pod koniec XIV i w XV wieku nastąpił wielki wzrost wydatków na dobra luksusowe i luksus osiągnął już spektakularne rozmiary. Poza królami, książętami i możnymi świeckimi ogromną rolę w tym procesie odegrał Kościól, który z jednej strony potępiał chełpienie się luksusowymi dobrami, $z$ drugiej - potrafił wydawać ogromne sumy na materialne przejawy swej potęgi. Francuski historyk pisze: „Zwalczał go również Kościół z przyczyn religijnych, chociaż wzniesienie takiej budowli jak pałac papieski w Awinionie pokazuje, że gdy w grę nie wchodziły przyjemności jednostki, lecz potwierdzenie zbiorowego prestiżu, wtedy papiestwo było jeśli nie najrozrzutniejszą, to jedną z najbardziej rozrzutnych instytucji Zachodu"18. Przejawy luksusu spotykały się zatem $\mathrm{z}$ ambiwalentnym przyjęciem: „Wieki XIV i XV były okresem uczt, które olśniewały i jednocześnie

16 P. McNeil, G. Riello, Historia luksusu, przeł. J. Jackowicz, Warszawa 2016, s. 32.

17 Por. M. Boczar, Św. Augustyna kategorie „uti” i ,frui”, „Przegląd Filozoficzno-Literacki” 2014 nr 3-4, s. 136. Zasadniczy pogląd Augustyna to ten, że napawać się należy tylko najwyższym dobrem, dobrem wiecznym, wszelkich zaś innych rzeczy należy używać w odniesieniu do ludzkich potrzeb. Co do traktowania ludzi, to Augustyn utrzymywał, iż będą oni przedmiotem radowania się w Bogu po życiu doczesnym.

18 J. Le Goff, Średniowiecze i pieniądze. Esej z antropologii historycznej, przeł. B. Baran, Warszawa 2011, s. 149. 
oburzały” ${ }^{19}$. Z jednej strony Kościół i lud gorszył się zbytkiem „nuworyszy”, z drugiej - zbytek ów był znakiem prestiżu w społeczeństwie ufundowanym na dużej nierówności pomiędzy grupami społecznymi.

Nowożytność oznacza narastanie zainteresowań wewnątrzświatowych i - oczywiście nierównomierne - pomnażanie luksusu aż do jego współczesnej demokratyzacji. Od połowy XIX wieku w świecie zachodnim ogromnie wzrosła liczba rzeczy codziennego użytku. Kapitalizm wyprodukował wielką biomasę przedmiotów, dalece przewyższającą biomasę przedmiotów naturalnych ${ }^{20}$. Kultura mieszczańska, np. właściwy krajom niemieckojęzycznym styl biedermeier, znalazła wielkie upodobanie w rzeczach, skupiając się nie tylko na ich wartościach sentymentalnych i historycznych, lecz także estetycznych ${ }^{21}$. Wiek XIX to czas narodzin konsumpcji w wymiarze masowym ${ }^{22}$. Mnożą się specjalistyczne sklepy, powstają pasaże handlowe i wielkie domy towarowe, a ich architektura bywa bardzo wysmakowana ${ }^{23}$. Przedmioty doczekują się

19 J. Le Goff, Średniowiecze i pieniądze. Esej z antropologii historycznej, dz. cyt., s. 150.

20 Por. J. Osterhammel, Historia XIX wieku. Przeobrażenie świata, red. nauk. i posłowie W. Molik, przeł. zespól, Poznań 2013, s. 302-320.

${ }^{21}$ Biedermeier, styl estetyczny i wnętrzarski, panował w latach 1815-1848. Bywa uznawany za czas narodzin designu, dobrego wzornictwa przemysłowego. W obrębie tego bowiem stylu odrzucono mającą długą tradycję zasadę, zgodnie z którą to „człowiek jest dla mebla” na rzecz przeciwnej, uznającej użyteczność przedmiotów i zgodne z nią projektowanie.

${ }^{22}$ Z opracowań ogólnych zob.: F. Bylok, Konsumpcja, konsument i społeczeństwo konsumpcyjne we współczesnym świecie. Studium socjologiczne, Katowice 2013; Ł. Iwasiński, Socjologiczne dyskursy o konsumpcji, Gdańsk 2016. L. Hostyński, Moralne problemy konsumpcji, Warszawa 2015. Na temat luksusu: U. Jarecka, Luksus w szarej codzienności. Społeczno-moralne konteksty konsumpcji, Warszawa 2013; Luksus versus niedostatek. Społeczno-ekonomiczne tło konsumpcji, red. U. Jarecka, Warszawa 2013; D. Thomas, Luksus. Dlaczego stracit blask, przeł. E. McIver, Warszawa 2010. O społecznym życiu przedmiotów: Gadżety popkultury. Społeczne życie przedmiotów, red. W. Godzic, M. Żakowski, Warszawa 2007; W stronę socjologii przedmiotów, red. M. Krajewski, Poznań 2005; A. Boćkowska, Księżyc z Pewexu. O luksusie w PRL, Wołowiec 2017. Kategorie luksusu i splendoru analizuje: S. Gundle, Glamour. A History, Oxford 2008.

${ }^{23}$ W Polsce przykładem luksusowego domu towarowego był i jest sklep Braci Jabłkowskich w Warszawie. Zob. C. Łazarewicz, Sześć pięter luksusu. Przerwana historia Domu Braci Jabłkowskich, Kraków 2013. Na Węgrzech zwraca uwagę Várkert Bazár w Budapeszcie. Został wybudowany według planu Miklósa Ybl na brzegu Dunaju jako granica ogrodów królewskich. Otwarto go w 1883 roku. Jest jednym z przykładów najdoskonalszej architektury neorenesansowej, ze świetnie wyważonymi proporcjami i piękną ornamentyką. Warto przypomnieć pasaże Paryża, Neapolu i domy 
przemyślanej ekspozycji na wystawach. Zainteresowaniu rzeczami i budzeniu ich pożądania sprzyjają wielkie wystawy światowe. Długi i złożony proces prowadzi do powstania współczesnych galerii handlowych o często pretensjonalnej i mocno sfunkcjonalizowanej architekturze oraz do nabywania rzeczy $\mathrm{w}$ sklepach i serwisach internetowych ${ }^{24}$. Wiele dóbr luksusowych stało się dostępnych dla przeciętnego klienta, co nie oznacza, iż on sam realnie zajął uprzywilejowaną społecznie pozycję: „Zachowanie klientów poszukujących tanich dóbr «luksusowych» może się wydawać «dobijaniem się» do świata, który nie jest dostępny inaczej niż poprzez ten właśnie konkretny przedmiot - «luksusowy» artykuł. Jednak nie jest on bramą do takiego świata. Jest fetyszem lub pamiątką z wyprawy, która odbywa się w wyobraźni" ${ }^{25}$.

Skupieniu na rzeczach sprzyja reklama. Multiplikacja obrazów rzeczy skutkuje zjawiskiem, które Baudrillard nazwał wzrostem mocy rzeczy ${ }^{26}$. Intensywnie reklamowana para butów Nike staje się powszechnie rozpoznawalnym przedmiotem pożądania, którego posiadanie skutkuje społecznym prestiżem. Reklama fetyszyzuje rzecz: otacza ją aurą obiektu o nadnaturalnych własnościach i mocy. Jej obrazowe reprezentacje ulegają tu pomnożeniu, a także powiększeniu, które dokonuje ekspozycji detali i kieruje uwagę na ich niektóre - atrakcyjne, wabiące - jakości (fakturę, połysk powierzchni, imaginowane własności haptyczne, wyobrażony zapach). Z kolei poprzez multiplikację reprezentacji części rzeczy ulegają sfetyszyzowaniu także owe części, elementy rzeczy. Na przykład firmy sprzedające rowery eksponują w katalogach reklamowych ich elementy (siodełka, koła, korby, pedały, a nawet poszczególne śruby) jako samoistnie atrakcyjne towary. Proces ten zdaje się nie mieć końca.

towarowe Londynu, przede wszystkim Harrods (1905). Pierwszym analitykiem przestrzeni pasaży i związanych z nimi doświadczeń był Walter Benjamin.

${ }^{24}$ Kupowanie rzeczy w sieci zapewnia jeszcze dodatkowe, nowe przyjemności. Pierwsza to przyjemność oczekiwania na zakupiony towar. Druga - mówi o niej Krajewski - to przyjemność kreacji: kupujący przemienia obrazy i reprezentacje w realne przedmioty. Zob. M. Krajewski, POPamiętane, Gdańsk 2006, s. 164.

${ }^{25}$ U. Jarecka, Luksus w szarej codzienności. Społeczno-moralne konteksty konsumpcji, dz. cyt., s. 88.

${ }^{26}$ J. Baudrillard, Społeczeństwo konsumpcyjne: jego mity i struktury, przeł. S. Królak, Warszawa 2006, s. 105 n. 
Współczesna popkultura pełna jest fetyszy. Są one silnie powiązane z konsumpcjonizmem. Fetyszem jest Coca Cola, kawa, McDonald's. Silnie fetyszyzowane są dżinsy, zwłaszcza w USA i Japonii; za egzemplarze z pierwszych serii pochodzących z końca XIX wieku płaci się na aukcjach tysiące dolarów. Fetyszyzm upowszechniany jest przez subkultury muzyczne, np. hip-hop, gdzie markowe ubrania, czapki, buty i okulary mają moc uwodzenia wyobraźni i tworzenia tożsamości. Cała zresztą kultura muzyczna, a także fanowska sprzyja fetyszyzowaniu rzeczy: fetyszami stają się dla fanów przedmioty powiązane z ulubionymi wykonawcami (kostki do gry na gitarze, pałeczki perkusyjne) i graczami (koszulki, szaliki), a ich ekspozycja ma wiele podobieństw z traktowaniem relikwii. Fetyszyzm rozwijają media konwergentne, łączące kilka platform przekazu, które np. z Gry o tron tworzą książkę i serial, a dodatkowo zamawiają koszulki, kubki czy gry powiązane z głównym produktem. Status fetyszy uzyskują dziś auta, zwłaszcza auta dawne, klasyczne i rzadkie (jak produkowane w krótkich seriach ferrari, których zakup obwarowany jest warunkami, np. posiadaniem już egzemplarza auta tej marki) ${ }^{27}$. Nie może to dziwić zważywszy na fakt, że samochód jest obiektem, który jak żaden inny ma dla ludzi moc ogniskowania ich pragnień. Jako fetysze funkcjonują drogie produkty markowe, choćby galanteria, a zwłaszcza torebki L. Vuitton, oprawki okularowe Prada etc. ${ }^{28}$

${ }^{27} \mathrm{~W}$ dziejach motoryzacji status fetysza osiągnął, i to zaraz po swoim pojawieniu się na paryskich targach motoryzacyjnych w 1955 roku citroen DS19. Samochód ten dzięki rozwiązaniom technicznym oraz awangardowemu kształtowi i wykończeniom natychmiast stał się symbolem nowoczesności i francuskiego w niej przewodnictwa, co przenikliwie analizował Roland Barthes. Zob. R. Barthes, Mitologie, przeł. A. Dziadek, Warszawa 2013, s. 190-192. Z czasem aura DS19 się ulotniła, wyparły go inne, udoskonalone technicznie i stylistycznie auta.

${ }_{28}$ Fetyszem staje się samo, wykonane z jakiegokolwiek materiału, logo marki umieszczone na produkcie i nadające mu prestiżowy status. Gdy chodzi o konkretne logo-marki, to w roku 2003 marka projektanta mody Alexandra McQueena została uznana za najmodniejszą markę na świecie przed Bang i Olufsen, Agent Provocateur, Tate Gallery i Ducati. Por. A. Wilson, Alexander McQueen. Krew pod skórą, przeł. K. Maksymiuk, B. Czartoryski, M. Faber, Kraków 2016, s. 315. Na temat strategii sprzedawania najpierw marek, a dopiero potem produktów zob. dobrze udokumentowane i wciąż przejmujące analizy Naomi Klein w No Logo, przeł. H. Pastuła, Izabelin 2004, s. 21-160. 
W świecie mężczyzn, gdzie od XIX wieku strój - w myśl oświeceniowej teorii, iż mężczyzna reprezentuje element racjonalny - uległ ascetyzacji, co wiązało się z ograniczeniem biżuterii, status fetysza uzyskują drogie zegarki (np. Hublot, Tag Heuer, IWC). Właściwością społeczeństw konsumpcyjnych jest, że wokół markowych, starannie zaprojektowanych produktów ogniskują się ludzkie tożsamości: ludzie definiują swoją tożsamość poprzez identyfikację z produktami i osobami, które wybrały te same marki. Same firmy zaś sprzedają swe produkty wraz z wymyślonymi, powiązanymi z używaniem rzeczy stylami życia ${ }^{29}$. Z punktu widzenia tradycyjnej moralności świat tożsamości konsumeryjnych może wydawać się nie tylko dziwny, ale też infantylny. Fiksacja na punkcie materialnych przedmiotów - zwłaszcza zmysłowo atrakcyjnych, $\mathrm{np}$. barwnych lub miłych w dotyku - jest wszak właściwa dzieciom ${ }^{30}$.

\section{Fetyszyzm w rozpoznaniu literackim: od Pereca do Ellisa}

Zachodni kult marek i uzależnienie od prestiżowej konsumpcji, a także związane $\mathrm{z}$ nimi zaniżenie aspiracji życiowych ludzi zostały uchwycone przez Georgesa Pereca w latach 6o. ubiegłego stulecia. Jego powieść Rzeczy (Les Choses, 1965) ${ }^{31}$ przynosi opis młodego małżeństwa mieszkającego w Paryżu. Aktywność tej pary i jej aspiracje ograniczają się do nabywania rzeczy: mebli, dywanów, książek, drobiazgów. W trybie pożądania rzeczy - skutkującego nieuchronną melancholią, która jest jednak na tyle płytka, iż nie budzi refleksji - utrzymuje ich nabierający rozpędu przemysł reklamowy. Perec pisze o tych dwojgu ludziach niemal z czułością, oddaje upływ dekad ich życia, powolne spowijanie

29 Fetyszyzm nie jest domeną mężczyzn, jak się niekiedy twierdzi. Sam Freud przypisywał fetyszyzm kobietom w ich relacji do ubioru. Aspekt gender jest jednak istotny: wiele wnosi badanie obszarów, w jakich obie płci realizują swoje skłonności fetyszystyczne, np. samochody i sprzęt stereo u mężczyzn, a torebki i buty u kobiet.

30 Oto przykład frazy oddającej typowe wiązanie fetyszyzmu i infantylności: „Clifford, of course, had still many childish taboos and fetishes” (D. H. Lawrence, Lady Chatterley's Lover, New York 1968, s. 65).

31 G. Perec, Rzeczy, przeł. A. Tatarkiewicz, Kraków 2014. 
się rozczarowaniem. Są dla niego ofiarami systemu konsumpcji, który skutecznie fetyszyzuje rzeczy, czyniąc je jedynymi obiektami ludzkich pragnień.

Po dwóch od czasu Rzeczy Pereca dekadach rozwoju cywilizacji konsumpcyjnej ukazała się powieść Amerykanina Breta Eastona Ellisa (ur. 1964) American Psycho ${ }^{32}$ (1991). Jest to powieść, której napisanie wiele autora kosztowało, gdyż, jak mówił, główny bohater to po części on sam ${ }^{33}$. Przy bohaterze Ellisa postaci z Rzeczy to niewinni marzyciele. Są osobami, które kierują się smakiem. Ich sentymentalizm przejawia się w potrzebie otaczania się rzeczami ładnymi, z czasem - gdy ich gust ulega wyrafinowaniu - pięknymi. Natomiast dwudziestosześcioletni, upojony sukcesami makler Patrick Bateman - bohater American Psycho - nie tylko myśli o rzeczach jako produktach prestiżowych, nigdy nie zapomina o markach, a jego spojrzenie zawsze je dostrzega. Bateman szuka w przedmiotach oznak mocy i mnożników woli panowania. Posiadanie jakościowych rzeczy i wiedzy o markach służy mu niszczeniu innych ludzi. Również o ludziach myśli bądź jako o obiektach do erotycznej konsumpcji - jest mizoginem uprzedmiatawiającym kobiety - bądź jako o zagrażających mu w konsumowaniu rywalach. Frédéric Beigbeder porównuje Ellisa z Perecem, mówiąc o - dostrzeżonym przez obu - zwycięstwie rzeczy nad człowiekiem oraz o zastąpieniu wiary $\mathrm{w}$ Boga religią produktów ${ }^{34}$. „American Psycho to fresk opowiadający o tym, jak Człowiek pod koniec lat osiemdziesiątych (to data śmierci wszelkich utopii) postanowił z własnej woli pogrzebać się pod górą towarów"35.

American Psycho uświadamia czytelnikom, jak dalece od czasów Pereca zbrutalizowała się cywilizacja konsumpcji i jak bardzo wypełniła

32 B. Easton Ellis, American Psycho, przeł. J. Polak, Kraków 2005.

33 Por. F. Beigbeder, Pierwszy bilans po apokalipsie. Esej, przeł. M. Kamińska Maurugeon, Warszawa 2014, s. 386-391. Beigbeder przywołuje swoje wywiady z Ellisem przeprowadzone w Kaliforni. Ellis oddziałał na prozę Michela Houellebecqa i Jonathana Littella.

34 Zob. F. Beigbeder, Pierwszy bilans po apokalipsie. Esej, dz. cyt., s. 388.

35 F. Beigbeder, Pierwszy bilans po apokalipsie. Esej, dz. cyt., s. 390. Beigbeder mówi o American Psycho jako o „apokalipsie naszych czasów” - tamże. 
się przemocą. Ostrość komunikatów reklamowych uległa interioryzacji w podmiocie: konsumenci stali się tak samo brutalni i wyrafinowani, jak adresowane do nich reklamy. Bateman jest „ucieleśnieniem tłumionej przemocy giełdy", to everyman. Cynizm świata reklam - czyli przekonanie, że nic nie ma wartości, lecz wszystko ma cenę - jest tym samym cynizmem, który przenika język publiczny i język monologu wewnętrznego pogrążonego $\mathrm{w}$ depresji szaleńca, mającego się za człowieka sukcesu - Batemana, a niejako język nas wszystkich. Dlatego podczas lektury tej książki mamy nie tylko nieprzyjemne odczucie dehumanizacji świata, ale wręcz własnego współuczestnictwa w czymś nieludzkim.

\section{Zakończenie}

Wielu, zwłaszcza konserwatywnych, krytyków kultury podkreśla, że współczesne społeczeństwa Zachodu są ubogie w zasoby moralne. Nawet jeśli uznajemy taki ogólny osąd za zbyt surowy, musimy przyznać co najmniej to, że współczesne zasoby moralne są bardzo heterogeniczne, a przez to stanowią słabe źródło dla budowania tożsamości i słabe spoiwo społeczne. Paradoksalne jest to, iż uderzający w społeczeństwach konsumpcyjnych fetyszyzm towarowy, który starałem się przedstawić okazuje się stanowić spoiwo silne - wszyscy wszak jesteśmy konsumentami - ale bardzo zaniżające ludzkie możliwości i aspiracje.

Fetyszyzm towarowy uderza swoim antyhumanizmem. Sugeruje, że człowiek jest dodatkiem do rzeczy, że wartość osoby ludzkiej wyznaczają przedmioty, które ona posiada. Sugeruje - zwłaszcza w reklamie iż rozwój istoty ludzkiej polega przede wszystkim, jeśli nie wyłącznie, na pomnażaniu tego, co można posiadać. Cała zatem sfera być ulega degradacji na rzecz sfery mieć, którą uznaje się za pole właściwej realizacji człowieczeństwa.

Dokonując takiego osądu fetyszyzmu towarowego promowanego przez system konsumpcji, nie należy zbyt łatwo postponować innych odmian fetyszyzmu, którym hołdują współczesne społeczeństwa. Istnieją bowiem inne odmiany fetyszyzmu, które w naszych programowo racjonalnych społeczeństwach pełnią pozytywne, integrujące 
funkcje ${ }^{36}$. Czynią to choćby przez dostarczanie zestawów symboli podzielanych przez szerokie grupy ludzi. Mam na myśli oddziaływanie mechanizmów fetyszystycznych w takich obszarach jak sport, film, moda, sztuka, architektura, praktyki żywieniowe, kolekcjonerstwo i polityka. Badanie takich fetyszyzmów jest ważnym zadaniem nauk o kulturze, wymaga też wiele wysiłku interpretacyjnego, gdyż oddziałują one w niejasny i słabo zbadany dotąd sposób.

\section{Bibliografia}

Barthes R., Mitologie, przeł. A. Dziadek, wstęp M. Kłosiński, Warszawa 2013.

Baudrillard J., Społeczeństwo konsumpcyjne: jego mity i struktury, przeł. S. Królak, Warszawa 2006.

Beigbeder F., Pierwszy bilans po apokalipsie. Esej, przeł. M. Kamińska Maurugeon, Warszawa 2014.

Bellow S., Suma po przemyśleniach, przeł. T. Bieroń, Poznań 1998.

Boczar M., Sw. Augustyna kategorie „uti” i „frui”, „Przegląd Filozoficzno-Literacki” 2014 nr 3-4, s. 135-156.

Boćkowska A., Księżyc z Pewexu. O luksusie w PRL, Wołowiec 2017.

Bodei R., O życiu rzeczy, przeł. A. Bielak, przekład przejrzeli i poprawili M. Salwa i K. Skórska, Łódź 2016.

BöhmeH., Fetyszyzmi ikultura. Innateoria nowoczesności, przeł. M. Falkowski, Warszawa 2012. Bylok F., Konsumpcja, konsument i społeczeństwo konsumpcyjne we współczesnym świecie.

Studium socjologiczne, Katowice 2013.

Dant T., Kultura materialna w rzeczywistości społecznej: wartości, działania, style życia, przeł. J. Barański, Kraków 2007.

Drozdowski R., Obraza na obrazy. Strategie społecznego oporu wobec obrazów dominujących, Poznań 2006.

Ellis Bret E., American Psycho, przeł. J. Polak, Kraków 2005.

36 „Nic bardziej mylnego aniżeli teoria uznająca nowoczesność za postęp racjonalności” - mówi Hartmut Böhme przywołując myśl Bruna Latoura. Zob. H. Böhme, Fetyszyzm i kultura. Inna teoria nowoczesności, przeł. M. Falkowski, Warszawa 2012, s. 20. 
Gadżetypopkultury.Społeczneżycieprzedmiotów, red.W.Godzic,M.Żakowski, Warszawa2007. Gundle S., Glamour. A History, Oxford University Press 2008.

Hamlyn D. W., Being a Philosopher. The History of a Practice, London-New York 1994.

Hostyński L., Moralne problemy konsumpcji, Warszawa 2015.

Iwasiński Ł., Socjologiczne dyskursy o konsumpcji, Gdańsk 2016.

Jarecka U., Luksus w szarej codzienności. Społeczno-moralne konteksty konsumpcji, Warszawa 2013.

Klein N., No Logo, przeł. H. Pastuła, Izabelin 2004.

Krajewski M., POPamiętane, Gdańsk 2006.

Król Z., Powrót do świata. Dzieje uwagi w filozofii i literaturze XX wieku, Warszawa 2013. Lawrence D. H., Lady Chatterley's Lover, New York 1968.

Le Goff J., Średniowiecze i pieniadze. Esej z antropologii historycznej, przeł. B. Baran, Warszawa 2011.

Luksus versus niedostatek. Społeczno-ekonomiczne tło konsumpcji, red. U. Jarecka, Warszawa 2013.

ŁazarewiczC.,Sześćpięterluksusu. Przerwana historia Domu BraciJabłkowskich, Kraków 2013. Marks K., Kapitał, t. 1, ks. 1, Krytyka ekonomii politycznej, przeł. H. Lauer, Warszawa 1970. McNeil P., Riello R., Historia luksusu, przeł. J. Jackowicz, Warszawa 2016.

Osterhammel J., Historia XIX wieku. Przeobrażenie świata, red. nauk. i posłowie W. Molik, przeł. zespół, Poznań 2013.

Perec G., Rzeczy, przeł. A. Tatarkiewicz, Kraków 2014.

Pysiak J., Król i Korona Cierniowa. Kult relikwii we Francji Kapetyngów, Warszawa 2012.

Schuster M., Don DeLillo, Jean Baurillard and the Consumer Conundrum, New York 2008.

Sikora S., Kilka uwag o fetyszu i fotografii, w: Rzeczy i ludzie. Humanistyka wobec materialności, red. J. Kowalewski, W. Piasek, M. Śliwa, Olsztyn 2008, s. 237-260.

Spaemann R., Osoby. O różnicy między czymś a kimś, przeł. J. Merecki, Warszawa 2011. Szyjewski A., Fetyszyzm, w: Religia. Encyklopedia PWN, red. T. Gadacz, B. Milerski, t. 4, Warszawa 2002.

Taylor Ch., Źródła podmiotowości. Narodziny tożsamości nowoczesnej, przeł. zespół, wstęp A. Bielik-Robson, oprac. nauk. T. Gadacz, Warszawa 2012.

Thomas D., Luksus. Dlaczego stracił blask, przeł. E. McIver, Warszawa 2010.

W stronę socjologii przedmiotów, red. M. Krajewski, Poznań 2005.

Wilson A., Alexander McQueen. Krew pod skórą, przeł. K. Maksymiuk, B. Czartoryski, M. Faber, Kraków 2016. 


\section{Abstrakt}

\section{Rzecz jako fetysz. O moralności konsumpcji}

Pojęcie fetysza ma swe źródło w teoriach religii pierwotnych. Słowo „fetysz” wywodzi się z portugalskiego feitico. Fetyszami nazywano małe przedmioty materialne (idole, amulety) używane w kulcie religijnym. We współczesnej filozofii i studiach kulturowych pojęcia fetysza i fetyszyzmu są bardzo pomocne w opisie traktowania rzeczy w systemie masowej konsumpcji. Luksusowe marki czynią swe produkty obdarzonymi mocą i pełnymi heterogenicznych znaczeń, co sprawia, iż produkty te stają się obiektami kultu dla konsumentów. W ten sposób kształtuje się nowa religia - religia przedmiotów. Pośród dyskutowanych autorów są: K. Marks, G. Perec, Ch. Taylor, H. Böhme.

\section{Słowa kluczowe}

fetyszyzm, konsumpcja, konsumpcja masowa

\section{Abstract}

\section{The thing as fetish. On the morality of consumption}

The concept of fetish has its roots in the theory of primitive religion. The word fetish is derived from the Portuguese feitico. Fetishes were the small material objects (idols, amulets) used in religious worship. In comtemporary philosophy of culture and cultural studies it is very helpful to describe the treatment of things in the system of mass consumption by using the term fetish and the theory of fetishism. Luxury brands make their products powerful and full of heterogenic meanings, so these products become objects of the cult by customers. In this way arises the new religion - religion of products. Among discussed authors are: K. Marx, G. Perec, Ch. Taylor, H. Böhme.

\section{Keywords}

fetishism, consumption, mass consumption 